\title{
Seed priming: An approach towards agricultural sustainability
}

Anju B. Raj

Department of Agronomy, College of Agriculture Vellayani, Kerala Agricultural University, Thiruvananthapuram-695522 (Kerala), India

Sheeja K. Raj*

Coconut Research Station, Balaramapuram, Kerala Agricultural University, Thiruvananthapuram- 695501 (Kerala), India

*Corresponding author. E-mail: sheejakraj70@gmail.com

\section{Abstract}

Seed priming is controlled hydration of seeds to a level that allow pre-germinative metabolic activity to continue, but interrupt the emergence of the radicle. Seed priming improves seed performance, ensures uniformity and better establishment, enhances the yield in diverse environments, greater tolerance to environmental stress and helps to overcome dormancy. Change in seed water content, cell cycle regulation, modification of seed ultrastructure, management of oxidative stress and reserve mobilization are the major physiological and biochemical changes takes places during seed priming. Priming methods adopted should be simple and affordable for its easy spread and adaptability. Seed priming should be influenced by factors such as light, aeration, temperature, time and seed quality. Different methods of priming are hydropriming, osmopriming, halopriming, solid matrix priming, biopriming and hormonal priming. Seed priming had significant effect on agriculture. It will hasten and synchronize the germination, enhances the plant growth, have better stress resistance, increase the use efficiency of nutrients and water and have better weed suppression effect. The review paper discusses about seed priming, physiological and biochemical changes in seed priming, different methods of seed priming and its role in sustainable agriculture.

Keywords: Seed priming, Seed priming methods, Physiological and biochemical changes in seed priming, Seed priming in agriculture

\section{INTRODUCTION}

Seed is the integral factor in crop production. From the time immemorial seed quality is regarded as a cardinal element in the development of agriculture and evidences of this has been observed in old Vedic literatures. In Manu Smriti it is mentioned that "Subeejam Sukshetre Jayate Sampadyathe" that means good seed in good soil yields abundantly. The requisite for good quality seed for increased production was identified as early as in the beginning of twentieth century.

Importance of quality seed: Quality seed is an essential factor for higher yield in crops. Use of other inputs viz., manures, fertilizers, pesticides etc. depends on the quality of seed used. Compared to other inputs the cost and quantity of seed used is less but it is the basic tool for food security and carrier for the adoption of improved technologies in agriculture. It also decides the crop yield and returns from the crop raised. Hasanuzzaman (2015) reported that by the usage of good quality seeds agricultural productivity can be enhanced by $20-25$ percent. The success of crop production depends on the quality of seed used, hence quali-

\section{Article Info}

DOI:10.31018/jans.v11i1.2010

Received: February 7, 2019

Revised: February 27, 2019

Accepted: March 3, 2019

\section{How to Cite}

Raj, A.B. and Raj, S.K. (2019). Seed priming: $n$ approach towards agricultural sustainability. Journal of Applied and Natural Science, 11(1): 227-234 ty seed should have high genetic and physical purity, high germination percentage, high vigour, free from pest and diseases, should have physical appearances according to the specification of the variety, more shelf life and optimum moisture content.

Unpredictable and inconsistent rainfall, degradation of soils, inferior quality seed and changing climatic condition, limited access to reliable draft power affect crop establishment to a great extent. These adverse events ultimately lead to crop failure, which makes crop production expensive and lead poor farmers into debt. The livelihoods of the farmers must be improved through simple and effective means. Among the different means of solutions, seed priming is one of the simple and effective measure to establish the crop successfully in the field especially in dry land farming.

Seed priming: Seed priming is controlled hydration of seeds to a level that allow pre-germinative metabolic activity to continue, but interrupts actual emergence of the radicle. According to Choudhary et al. (2008) it is the controlled hydration of seed that restricts germination, but permits pre- 
germinative physiological and biochemical changes to occur. Seed priming is absolutely a seed improvement process for enhancing the germination attributes of seeds. It is practiced by partial hydration of seeds and retaining them under welldefined moisture, temperature and aerated conditions for a stipulate period of time. Seeds are optimally hydrated and metabolic processes occur up to a level prior to radicle emergence and thereby allowing important pre-germination steps to be fulfilled within the seeds during seed priming.

History of seed priming: Since right from the beginning of agriculture, man realized that most seeds do not germinate easily and uniformly. Seed priming was an age-old technique practiced by the Greek farmers. Theophrastus (372-287 BC) focused on seed physiology and suggested that germination process may be temporarily interrupted. He recommended the pre-soaking of cucumber seeds in milk or water to germinate earlier and vigorously (Evenari, 1984). Research reports also revealed that pre-hydration of legume seeds was done by Roman farmers in order to increase the germination rate and synchronize germination. In 1664, Evelyn mentioned that temperature prior to sowing may have an impact on further germination. During 1779, Ingenhousz studied the impact of light on seedling emergence. Amici during 1830 and Sachs during 1859 described the morphological process associated with seed germination (Amici, 1830; Sachs, 1859). The role of plant hormones in seed desiccation tolerance, reserve mobilization, cell division and cell elongation were discovered in 1920's (Lutts et al., 2016). The word seed priming was coined by Heydecker in 1973 and he successfully adopted seed priming to improve seed germination and emergence under stressful conditions (Sivasubramaniam et al., 2011).

Present status of seed priming: Seed priming is a simple but successful solution for improved crop production. Among the seed priming techniques, hydro priming is commonly adopted by the farmers of India, Nepal, Pakistan, Botswana, Malawi and Zimbabwe. Centre for Arid Zone Studies (CAZS) prescribed "safe limits" (the maximum length of time for which seeds can be soaked) for the on-farm seed priming of maize, upland rice, wheat, chickpea and sorghum. On farm seed priming seems to be a reliable and a widely applicable technology. The International Crops Research Institute for the Semi-Arid Tropics (ICRISAT) has been promoting the use of chickpea in fallow cultivable areas of Bangladesh using on-farm seed priming. Average fifty per cent increase in yield had been observed in 30 on-farm trials. On-farm seed priming increased the yield of maize in Zimbabwe and India to a tune of 22 per cent, sorghum in Zimbabwe and Pakistan to a tune of 31 per cent, wheat in India and Pakistan to a tune of 37 percent and upland rice in West Africa to a tune of 70 percent (Das et al.,2015).

Seed germination process: A fast and synchronize crop emergence and rapid root growth is essential for good crop establishment. Germination of seeds commonly occurs in three well defined phases. Phase I is the imbibition phase, Phase II is the activation phase and Phase III is the germination phase where emergence of root and hypocotyle occurs from the seed. Phases I and III both involves an increase in the water content while hydration remains stable during Phase II. Germination remains reversible up to phase II, so the seeds can be dried again and stored in a viable state and they can re-initiate germination under favorable condition. Priming treatments may be applied during the reversible phase of germination. The treatments will vary according to the osmotic potential of the solution used for priming, time taken for priming, temperature at which the priming was done and the chemicals used for priming. Bewley and Black (1978) reported that the effective priming treatments activate the metabolic processes started during the phase II of germination, which are then temporally interrupted before a loss of desiccation occurs.

Seed priming process: Seed priming is partial hydration of seeds and metabolic activity is attained in a desirable manner thereby allowing important pre-germination steps to be initiated within the seeds. Repair of membranes, repair and synthesis of DNA and RNA, development of immature embryo, alterations of endosperm tissues surrounding the embryo, dormancy breakage and pre -germination metabolism enrichment are the major changes takes place during seed priming. Since seeds are physiologically closer to germination, primed seeds have increased germination rate, early germination, uniformity in germination, better growth attributes, faster emergence and better stand establishment (Farooq et al., 2007).

Physiological and biochemical changes during seed priming

Change in seed water content: During seed germination an initial rapid uptake of water is followed by a visible lag phase. Only after the germination is completed a further increase in water uptake occurs, as the embryonic axis elongates. Movement of water across cell membranes is essential for the initiation of metabolism and the water movement is mediated by aquaporins. Transmembrane proteins are aquaporins (AQPs) which plays a vital role in plant water relations. High expression of AQPs during priming increases the water transport across the plasma membrane which facilitate water supply to the expanding tissues and enhance the germination potential of primed seeds. This may be the reason for the faster imbibition of water by primed seeds in comparison with non-primed ones. The accumulation of os- 
motically active solutes such as amino acids, ammonium compounds and sugars during priming was noticed in several species and was shown to improve seed germination under subsequent water stress. Seeds also undergo dehydration during the priming process. LEAs (Late embryogenesis abundant proteins) accumulate during cell dehydration maintain the cell structure and macromolecules by inhibiting the aggregation and inactivation of proteins. The accumulation of LEAs helps the primed seed to overcome drought and other stresses viz., osmotic, cold and salt stress.

Cell cycle regulation: Benefits achieved in germination due to priming are based on its effect on DNA. Priming increases the replication of DNA and enable the advancement of cell cycle from $\mathrm{G} 1$ to $G 2$ phase. Activation of DNA repair mechanism is essential for the successful pre-activation of cell cycle and has been observed during seed imbibition preceding germination. Production of cyclin dependent protein kinases, mitochondrial biogenesis and increase in DNA polymerase activity occurs during pre-activation of cell cycle. The preactivation of cell cycle may be the possible reason for the better performance of primed seeds over unprimed ones.

Modification of seed ultrastructure: The growth potential of the embryo and the endosperm tissue surrounding the embryo determines the ability of seeds to germinate. The endosperm tissue surrounding the embryo act as a physical barrier in many crop species which arrests the germination process and obstruct the emergence of radicle. Xyloglucans are hemicellulose present in the cell membrane. XTH (Xyloglucan endotrans hydrolase) is an enzyme which has the ability to cleave xyloglucans and are engaged in cell wall loosening. Endo beta mannase are another enzyme involved in the hydrolysis of mannan rich cell walls of endosperm during germination and post germinative seedling growth. During priming, the activity of XTH get enhanced and there will be an increase in the production of endo beta mannase and simultaneously, it will result in cytoskeleton reorganization which is necessary for cell wall loosening. These modifications will speed up the germination process.

Management of oxidative stress: Management of oxidative status is observed as an important part of primed seed physiology. The water imbibition and subsequent dehydration during priming process are accompanied by a generation of reactive oxygen species (ROS). At that time an antioxidant defence mechanism will activate. It acts as ROS scavengers and regulates the ROS production. The management of oxidative status in primed seeds leads to protection against oxidative stress and recovery from aging.

Reserve mobilization: Germination related processes such as respiration, energy metabolism and early reserve mobilization occur during priming. Priming increases the ATP production, energy charge and ATPIADP ratio. The enzymes responsible for the mobilization of storage protein, carbohydrate mobilization ( $\alpha$ and $\beta$ amylases) and lipid mobilization (isocitrate lyase) were either synthesized or activated during priming. Higher energy turnover and increased metabolism rate in primed seeds which lead to better germination and stress tolerance.

Arun et al. (2017) studied the effect of seed priming on enzyme activity of summer cowpea. The results of the study revealed that the peroxidase activity was higher for seeds treated with $10^{-3} \mathrm{M}$ ammonium molybdate and the catalase and amylase activity was higher for seeds treated with 100 ppm gibberellic acid.

Factors affecting priming: The major factors influencing seed priming are light, aeration, temperature, time and seed quality.

Aeration: Aeration influences the seed respiration and viability which contributes to synchronize germination and assures a safer seed habitat. However, the effect of aeration varies with the species.

Light: Light effect is varied widely with species. Beneficial effect of seed priming could be modified by light quality. Nakamura et al. (1982) reported that primed celery seeds had more germination at high temperature when priming treatment was done under light than in the dark.

Time: Duration of the priming process varies according to the type of osmotica, osmotic potential of the solution and temperature during priming. Cantiliffe et al. (1988) studied the effect of duration of priming on pepper seeds and revealed that seeds primed for 6 days had the fastest germination compared to seeds primed for 4 or 5 days.

Temperature: If the soaking temperature is maintained below the optimum range then the radicle growth during priming may be restricted. Haigh et al. (1987) reported that seed priming for 14 days at $15^{\circ} \mathrm{C}$ was found more effective in improving the seed germination of tomato, carrot and onion than that at $25^{\circ}$ C. Similarly, Cantiliffe (1981) opined that germination percentage of lettuce was greater for priming at $15^{\circ} \mathrm{C}$ compared to 5 or $25^{\circ} \mathrm{C}$.

Osmotic potential: Osmotic potential of the solution is another factor affecting the effectiveness of priming. Ali et al. (1990) reported that germination of tomato seeds primed in a solution having an osmotic potential of -0.58 to $-0.86 \mathrm{MPa}$ was found to be more compared to solution having an osmotic potential of -1.19 or $-1.49 \mathrm{Mpa}$. Singh et al. (1985) observed that higher rate of germination was observed in celery seeds primed with PEG $6000 @ 300 \mathrm{~g} \mathrm{~L}^{-1}$ compared to $400 \mathrm{~g} \mathrm{~L}^{-1}$.

Advantages of seed priming: Seed priming helps in better seedling establishment and ensures uniformity in germination. Uniform emergence helps to optimize harvesting efficiency which can in- 
crease the yield potential of a crop. Seed priming can also improve the seed performance such as germination speed, mean germination time, germination index, germination rate index, seedling vigour etc. Primed seeds performed better under diverse environments especially under sub optimal conditions at sowing viz., temperature extremes, excess moisture and resulted in higher yield compared to unprimed seeds Greater tolerance to environmental stresses helps to overcome dormancy was also reported by Caseiro et al. (2004).

Methods of seed priming: Several types of seed priming methods have been developed and used successfully in order to invigorate the seeds and alleviate the environmental stress.

Hydropriming: Hydropriming is the simplest method of seed priming. It is the simple soaking of seeds in water for a definite period of time. This process is especially useful in dry farming and dry land framing areas. In hydropriming, seeds are either soaked in water with or without aeration. Taylor et al. (1998) reported that in hydropriming, water enters in to the seed freely and the entry of water into the seed is solely influenced by the affinity of the seed tissue for water. Since no chemical substances are involved in hydropriming it is the cheap and ecofriendly method which can be easily adopted by the farmers. The main disadvantage of hydropriming is the uncontrolled water imbibition which leads to unequal degree of seed hydration thus leading to unsynchronized emergence. Hence, in hydropriming, duration of soaking seeds in water, volume of water used for soaking and the temperature at which the priming is done are very important.

Eskandari (2012) studied the effect of hydropriming in tomato. The results revealed that hydropriming increased the germination percentage (84 percent), speed of germination (6.83 days) and seedling dry weight $(24 \mathrm{mg})$ compared to control. Studies on the effect of hydropriming on the germination vigour of maize inbred line B73 revealed that 87 percent increase in final germination percentage and higher vigour index of 112.17 were recorded in hydroprimed seeds as compared to control (Dezfuli et al., 2008).

Halopriming: Halopriming is soaking seeds in inorganic salt solutions such as $\mathrm{NaCl}, \mathrm{KCl}$ etc. Even under adverse environmental conditions viz., temperature extremes, oxygen deprived condition, halopriming promotes uniform germination and better crop performance. Halopriming is a simple and cheap agro-technique which ensure better synchrony of emergence and crop stand under various conditions of environment. Halopriming with $\mathrm{KNO} 3$ (5 percent) and $\mathrm{NaCl}$ (5 percent) were reported to bring about enhancement in seedling vigour in tomato (Venkatasubramanian and Umarani, 2007). Singh and Pandey (2003) also observed improvement in germination of onion when seeds were haloprimed with 150 ppm KNO3.

Osmopriming or Osmoconditioning: Osmopriming also called osmoconditioning, is the soaking of seeds in osmotic solutions containing chemicals such as mannitol, polyethylene glycol (PEG), sorbitol, glycerol etc. Due to the low water potential of osmotic solutions, seed uptake water slowly which permits seed imbibition and activation of early phases of germination but hinder radicle protrusion. In general, the osmotic potential of the priming solution is usually in the range of -1 to $-2 \mathrm{MPa}$ but it varies with the species and duration of the priming treatment. Because of its large molecular size, polyethylene glycol is the common chemical used in osmopriming treatment. Arif et al. (2008) reported that the osmpriming with PEG significantly enhanced the seed emergence and grain yield of soybean compared to control.

Solid matrix priming: Solid matrix priming (SMP) or matriconditioning is an alternative to osmopriming due to the high cost of osmotic agents and technical problems with aeration in osmopriming (Paparella et al. 2015). This method involves the incubation of seeds in a solid insoluble matrix (vermiculite, diatomaceous earth, peat moss, charcoal, sand and clay) with a limited amount of water and confers a slow imbibition (Mondal and Bose, 2014).

In solid matrix priming, seeds are mixed and incubated with wet solid water carrier for a definite period of time after that seeds are removed from the matrix, washed and dried back to the original moisture content. Solid insoluble medium allows the seeds to hydrate moderately and act very similar to that of imbibition process takes place in the soil. Materials used as matrices should have high water holding capacity, low matrix potential, low solubility in water, large surface area, nontoxic to seeds and have the ability to stick to the surface of seed.

Experiment conducted with an objective to find out the effect of solid matrix priming on the fruit yield of bitter gourd revealed that significant increase in fruit yield was observed due to solid matrix priming compared to control. Among the treatments, solid matrix priming with perlite recorded higher fruit yield (16.22 kg plot ${ }^{-1}$ and $250.35 \mathrm{~kg} \mathrm{ha}^{-1}$, respectively) (Kanwar et al., 2017).

Biopriming: Biopriming is a seed treatment which combines the inoculation of seed with beneficial microorganisms (biological aspect) and regulation of seed hydration (physiological aspect) for biotic and abiotic stress management (Bisen et al., 2015). Microorganisms have the potential to proliferate, colonize and produce plant growth regulators (PGR's) during biopriming. Besides, biopriming has a favourable influence on germination and seedling emergence, it safeguards the seeds 
against the soil and seed-borne diseases. Beneficial microorganisms used in biopriming are able to colonize and proliferate in the rhizosphere and support plant both directly and indirectly. In pearl millet, biopriming with Pseudomonas fluorescens isolates enhanced plant growth and resistance against downy mildew disease (Raj et al., 2004). Sivakalai and Krishnaveni (2017) reported that biopriming of Pumpkin seeds with Azospirillum 10 $\%+$ Phosphobacteria $20 \%+$ Pseudomonas fluorescens $20 \%$ improved the plant growth, seed yield and quality.

Hormonal priming (Hormopriming): Hormonal priming or hormopriming is the seed treatment of seeds with different hormones which encourages the growth and development of the seedlings. Commonly used hormones are abscisic acid, auxins, gibberellins, kinetin, ethylene, polyamines and salicylic acid (SA). Galhaut et al. (2014) reported that in heavy metal polluted soil, gibberellic acid (GA3) priming improved the photosynthetic activity, antioxidant system, seedling emergence and growth of white clover. lqbal and Ashraf (2013) reported that hormopriming with $\mathrm{GA}_{3}$ increased salt tolerance and grain yield in spring wheat. Polyamine priming impart drought tolerance in rice (Farooq et al., 2006). The effect of hormonal priming in chick pea was studied by Mazed et al. (2015) and revealed that higher number of seeds per pod and grain yield was observed in seeds treated with $225 \mathrm{ppm}$ gibberellic acid.

Role of seed priming in sustainable agriculture: Seed priming is a simple cost-effective technique which can be easily adopted by the farmers to improve the plant behavior in field. Research evidences revealed that seed priming has favourable influence on seed germination, plant growth, nutrient use, stress tolerance etc.

Effect on hastening and synchronization of germination: Priming ensures uniformity in germination, earlier germination and higher germination rate. Priming help to synchronize endosperm weakening, embryo cell elongation and reserve mobilization. Priming initiate the repair and reactivation of pre-existing mitochondria and to initiate the biogenesis of new ones (Sun et al., 2011). It may thus provide a greater level of energy over a short time to sustain final germination. In an experiment in rice, Hariss and Jones (1997) reported that hydropriming of paddy seeds for $12-24 \mathrm{~h}$ reduced the germination time by 50 percent. Similarly, hydropriming of maize seeds improved the germination and field emergence (Arif et al., 2005). Arif et al. (2008) observed that soybean seeds primed for $6 \mathrm{~h}$ hastened and synchronized the emergence and increased the grain yield. Jalali and Salehi (2013) reported that a faster emergence may help to increase competitivity of cultivated plants against weed species for sugarbeet.
Effect on plant growth: Primed seeds grow faster than unprimed ones. This might be due to the rapid seedling establishment. Singh et al. (2016) reported that in rice seed priming with 5aminolevulinic acid enhanced shoot length while priming with picomolar rutin enhanced both root and shoot length. Juraimi et al. (2012) studied the effect of seed priming on seedling vigour of aerobic rice variety and observed that the highest seedling vigour index was recorded in hydro priming. Shoot length, root length, and dry matter was the highest in seeds primed with chemical zappa. Arun et al. (2017) reported that priming increases the growth and yield of summer cowpea. The seed weight plant $^{-1}$, 1000 seed weight and seed yield were the highest for seeds treated with $10^{-3}$ $\mathrm{M}$ ammonium molybdate. The beneficial effect of priming on plant growth may be due to increased nutrient use efficiency (Muhammad et al., 2015) or due to better regulation of the plant water status (Ahmed et al., 2016). Jisha and Puthur (2015) revealed that priming with $\beta$-aminobutyric acid favourably influenced the cell cycle regulation and cell elongation processes which may contribute to improved growth of seedlings in Vigna radiata. Seed priming with $\mathrm{NaCl}$ and $\mathrm{GA}_{3}$ improved the growth of medicinal plants viz., Calendula officinalis and Foeniculam vulgare under environmental stress conditions (Sedhgi et al., 2010)

Effect on stress resistance: Many studies suggested that primed seeds showed clear improvement of resistance to environmental constraints. Priming may impart resistance to biotic stresses such as Fusarium oxysporum in tomato (Krol et al., 2015), viral disease in Brassica rapa (Kalischuk et al., 2015) and downy mildew in pearl millet (Anup et al., 2015. Varma et al. (1984) observed that priming with $\mathrm{GA}_{3}$ accelerate the germination processes before germination and thus resulted in good germination under salinity stress condition with low moisture. Sedghi et al. (2010) reported that higher germination rate and germination percentage of medicinal plants, Calendula officinalis and Foeniculam vulgare under saline stress condition might be due to the increased activity of super oxide dismutase and peroxidase. Emergence percentage of haloprimed chilly seeds was significantly higher compared to unprimed seeds under saline conditions (Khan et al., 2009). Priming of maize seeds with ascorbic acid reduced aluminium stress (Alcantara et al.,2015). Mahmoudi et al. (2012) reported that hydropriming of lettuce reduces the ill effects of $\mathrm{NaCl}$ induced stress. Priming rice seeds with calcium chloride for $24 \mathrm{~h}$ with an osmotic potential of $-1 \mathrm{MPa}$ reduced the injurious effects of salinity stress (Yousof, 2013).

Effect on nutrient use efficiency: Enhancement in nutrient use efficiency may be as result of priming induced overexpression of genes encoding for 
specific transporters. Priming increase the nitrate reductase enzyme activity which will improve $\mathrm{N}$ nutrition in plants (Singh et al., 2015). Jamil et al. (2014) reported that in cereals, phosphorus priming reduced the infestation by parasite weed Striga hermonthica. Pame et al. (2015) revealed that in rice, $P$ uptake can be increased by nutripriming with $\mathrm{P}$. Priming with $\mathrm{Si}$ enhanced the Si content of cultivated plants and it will strengthen the plant resistance to biotic and abiotic stresses (Ahmed et al., 2016). Effect of nutri priming with $\mathrm{Zn}$ on yield attributes of maize was studied by Harris et al. (2007) and observed that seed priming with 1 percent $\mathrm{Zn}$ and soil application of $2.75 \mathrm{~kg} \mathrm{Zn} \mathrm{ha}{ }^{-1}$ recorded comparable results in terms total biomass, straw yield, cob yield, grain yield, shelling percentage and 1000 grain weight.

Effect on weed suppression: Vigorous crop stands with rapid canopy development resulting from the synchronized emergence of primed seeds have better competitive ability over weeds and suppress the weeds better than unprimed seeds (Ghiyasi et al., 2008, Anwar et al., 2012). Similar observations were also made by Harris et al. (2002). Singh et al. (2012) reported that in upland rice seed invogouration techniques (seed hardening, priming with $\mathrm{KCl}$ and hormonal priming with $\mathrm{GA}_{3}$ ) significantly reduced the dry weight of weeds at harvest. Seed priming effect on weed suppression and phenology of aerobic rice was studied by Juraimi et al. (2012) and they revealed that the weed dry weight, weed density and relative yield loss over weed free control was higher for unprimed seeds than the primed seeds. Hence it can be concluded that primed seeds have suppressive effect on weeds. Halopriming enhanced the competitive ability of wheat crop against weeds (Meena et al, 2013).

Effect on water use efficiency: Early and synchronized field emergence observed in seed priming treatments resulted in more leaf area and early canopy development. Evaporation loss will be reduced due to better ground cover. Also, early emergence resulted in vigorous plants with deeper and more extensive root systems which are capable of extracting water from the deeper layers even under lower irrigation regimes. Hence water use efficiency increases due to priming which in turn increases the yield of crops. In summer cowpea priming with Ammonium molybdate $10^{-3} \mathrm{M}$ increases the WUE two times than control (Arun et al., 2017). Ali et al. (2013) observed that hydropriming of wheat seeds for $12 \mathrm{~h}$ increased the water use efficiency of late sown wheat crop under different irrigation regimes (80\% ETo and 100 $\%$ ETo). On farm results revealed that seed priming improved the drought tolerance in crop plants (Harris et al., 2002). Better crop establishment due to hydropriming increased tolerance to dry spell and save irrigation in rice wheat cropping system (Meena et al., 2013).

\section{Conclusion}

Seed priming is an environmentally safe and effective technology which can be easily adopted by resource-poor farmers and benefited the farmers in a number of ways. It may indeed considered as a valuable strategy to improve stand establishment under adverse agro- climatic conditions (rainfed, dry farming and dry land farming regions) with enhanced yield, increased tolerance to stress situations, increased resistance against diseases, enhanced crop competitiveness against weeds and increased water use efficiency. Hence it can be concluded that seed priming is a tool for sustainable agriculture.

\section{REFERENCES}

1. Ahmed, M., Qadeer, U., Ahmed, Z. I., and Hassan, F. U. (2016). Improvement of wheat (Triticum aestivum) drought tolerance by seed priming with silicon. Arch. Agron. Soil Sci. 62: 299-315.

2. Alcantara, B. K., Machemer-Noonan, K., Silva Junior, F. G., and Azevedo, R. A. (2015). Dry priming of maize seeds reduces aluminum stress. PLOS ONE. [e-journal] 10(12): e0145742. Available: https:// doi.org/10.1371/journal.pone.0145742 [28 Nov. 2018].

3. Ali, A., Machado, V. S., and Hamill, A. S. (1990). Osmoconditioning of tomato and onion seeds. Scientia Horticulturae. 43(3-4): 213-224.

4. Ali, H., Iqbal, N., Shahzad, A.N., Sarwar,N., Ahmad, S., and Mehmood, A. (2013). Seed priming improves irrigation water use efficiency, yield and yield components of late sown wheat under limited water conditions. Turk. Agric. For. 37: 534-544.

5. Amici, G. B. (1830). Note on pollen action mode on stigmata. Annales Sciences NaturellesBotanique. 21: 329-332.

6. Anup, C. P., Prasad, M., Nataraj, S., Mayuri, N. G., Manbali, J., Hussain, A., and Kukkundoor, R. K. (2015). Proteomic analysis of elicitation of downy mildew disease resistance in pearl millet by seed priming with $\beta$-aminobutyric acid and Pseudomonas fluorescens. J. Proteomics 120:58-74.

7. Anwar, M. P., Juraimi, A. S., Puteh, A., Selamat, A., Rahman, M. M., and Samedani, B. (2012). Seed priming influences weed competitiveness and productivity of aerobic rice. Acta AgriculturaeScandinavica Section B-Soil Plant Sci. 62 (6):499-509.

8. Arif, M., Ali, S., Shah, A., Javed, N., and A. Rashid. (2005). Seed priming maize for improving emergence and seedling growth. Sarhad J Agric. 21: 17-20.

9. Arif, M., Jan, M. T., Marwat, K. B., and Khan, M. A. (2008). Seed priming improves emergence and yield of soybean. Pak. J. Bot. 40(3): 1169-1177.

10.Arun, M. N., Hebbar, S. S., Bhanuprakas, K., and Senthivel, T. (2017). Seed priming improves irrigation water use efficiency, yield and yield components of summer cowpea under limited water conditions. Legume Res. 40(5): 864-871.

11.Bewley, J. D. and Black, M. (1978). Physiology and Biochemistry of Seeds in Relation to Germination. Springer-Verlag, New York, pp. 305-375.

12.Bisen, K., Keswani, C., Mishra, S., Saxena, A., 
Rakshit, A., and Singh, H. B. (2015). Unrealized potential of seed biopriming for versatile agriculture. In: Rakshit, A., Singh, H. B., and Sen, A. Nutrient Use Efficiency: from Basics to Advances (1stEd.). Springer, New Delhi, pp. 193-206.

13.Cantiliffe, D. J. (1981). Priming of lettuce for early and uniform emergence under conditions of environmental stress. Acta. Hortic. 122: 29-38.

14.Cantiliffe, D. J., Elballa, M., Guedes, A., Odell, G. B., Perkins-Veazie, P., Schultheis, J. R., Seale, D. N., Shuler, K. D., Tanne, I., and Watkins, J. T. (1988). Improving stand establishment of direct seeded vegetables in Florida. Proc. Florida State Hortic. Soc. 100: 213-216.

15.Caseiro, R., Bennett, M. A., and Marcos-Filho, J. (2004). Comparison of three priming techniques for onion seed lots differing in initial seed quality. Seed Sci. Technol. 32(2): 365-375.

16.Choudhary, D. K., Johri, B. N., and Prakash, A. (2008). Volatiles as priming agents that initiate plant growth and defence responses. Curr. Sci. 94 (5): 595 $-604$.

17.Das, A., Boruah, R., Sharma, S. M., and Pegu, J. (2015). Seed priming - An effective method for crop production. Int. J. Crop Improv. 6(1): 83-86.

18.Dezfuli, P. M., Sharif-Zadeh, F., and Janmohammadi, M. (2008). Influence of priming techniques on seed germination behavior of maize inbred lines (Zea mays L.). J. Agric. Biol. Sci. 3(3): 22-25.

19.Eskandari, H. (2012). Germination and field performance of differentially matured seeds of tomato (Lycopersiconesculentum) as affected by seed priming. Int. J. Agric. Res. Rev. 2(6): 857-861.

20.Evelyn, J. S. (1664). A Discourse of Forest Trees and the Propagation of Timber. John Martin (Royal Society), London, 218p.

21.Evenari, M. (1984). Seed physiology: Its history from antiquity to the beginning of the 20thcentury. Bot. Rev. 50:119-142.

22.Farooq, M., Basra, S., Tabassum, M. A. R., and Afzal, I. (2006). Enhancing the performance of direct seeded fine rice by seed priming. Plant Prod. Sci. 9 (4): 446 - 456.

23.Galhaut, L., Lespinay, A., Walker, D. J., Bernal, M. P., Correal, E., and Lutts, S. (2014). Seed priming of TrifoliumrepensL. improved germination and early seedling growth on heavy metal contaminated soil. Water Air Soil Pollut. 225: 1-15.

24.Ghiyasi, M., Seyahjani, A. A., Tajbakhsh, M., Amirnia, R., and Salehzadeh, H. (2008). Effect of osmopriming with polyethylene glycol (8000) on germination and seedling growth of wheat (Triticum aestivumL.) seeds under salt stress. Res. J. Biol. Sci. 3 (10): 1249-1251.

25.Haigh, A. M. and Barlow, E. W. R. (1987). Germination and priming of tomato, carrot, onion and sorghum seeds in a range of osmotica. J. Am. Soc. Hortic. Sci. 112: 202-208.

26. Harris, D. and Jones, M. (1997) On Farm seed priming to accelerate germination in rainfed, dry-seeded rice. Int. Rice Res. Notes. 22 (2): 30.

27.Harris, D., Rashid, A., Miraj, G., Arif, M., and Shah, H. (2007). 'On-farm' seed priming with zinc sulphate solution - A cost-effective way to increase the maize yields of resource-poor farmers. Field Crops Res. 102(2): 119-127.

28.Harris, D., Tripathi, R. S., and Joshi, A. (2002). On- farm seed priming to improve crop establishment and yield in dry direct-seeded rice. In: Pandey, S., Mortimer, M., Wade, L., Tuong, T. P., Lopes, K., and Hardy, B. (eds), Direct Seeding: Research Strategies And Opportunities. International Rice Research Institute, Manila, Philippines, pp. 231-240.

29. Hasanuzzaman, M. (2015). Seed Quality [on-line]. Available: https://hasanuzzaman.weebly. com/ uploads/9/3/4/0/934025/seed_quality.pdf [15 Nov. 2018].

30.Ingenhousz, J. (1779). Experiments upon Vegetables. Elmsly and $\mathrm{H}$. Payne, London, 455p.

31.lqbal, M. and Ashraf, M. (2013). Gibberellic acid mediated induction of salt tolerance in wheat plants: Growth, ionic partitioning, photosynthesis, yield and hormonal homeostasis. Environ. Exp. Bot. 86: 76-85.

32.Jalali, A. H. and Selehi, F. (2013). Sugar beet yield as affected by seed priming and weed control. Arch. Agron. Soil Sci. 59: 281-288.

33.Jamil, M., Charnikhova, T., Verstappen, F., Ali, Z., Wainwright, H., and Bouwmeester, H. (2014). Effect of phosphate-based seed priming in strigolactone production in Striga hermonthicainfection in cereals. Weed Res. 54: 207-313.

34.Jisha, K. C. and Puthur, J. T. (2015). Seed priming with BABA ( $\beta$-amino butyric acid): a cost- effective method of abiotic stress tolerance in Vigna radiata (L.) Wilczek. Protoplasma. 253(2): 277-289.

35.Juraimi, A. S., Anwar, M. P., Selamat, A., Puteh, A., and Man, A. (2012). The influence of seed priming on weed suppression in aerobic rice. Pak. J. Weed. Sci. Res. 18: 257- 264.

36.Kalischuk, M. L., Johnson, D., and Kawchuk, L. M. (2015). Priming with a double-stranded DNA virus alters Brassica rapaseed architecture and facilitates a defense response. Gene. 557: 130-137.

37.Kanwar, R. and Mehta, D. K. (2017). Studies on solid matrix priming of seeds in bitter gourd (Momordica charantiaL.). J. Appl. Nat. Sci. 9(1): 395-401.

38.Khan, H. A., Ayub, C. M., Pervez, M. A., Bilal, R. M., Shahid, M. A., and Ziaf, K. (2009). Effect of seed priming with $\mathrm{NaCl}$ on salinity tolerance of hot pepper (Capsicum annuum L.) at seedling stage. Soil Environ. 28(1): 81-87.

39.Krol, P., Igielski, R., Pollmann, S., and Kepczynska, E. (2015). Priming of seeds with methyl jasmonate induced resistance to hemibiotrophFusarium oxysporumf. sp. Lycopersici in tomato via 12-oxophytodienoic acid, salicylic acid, and flavonol accumulation. J. Plant Physiol. 179: 122-132.

40.Lutts, S., Benincasa, P., Wojtyla, L., Kubala, S. S., Pace, R., Lechowska, K., Quinet, M., and Garnczarska, M. (2016). Seed priming: New comprehensive approaches for an old empirical technique. In: New Challenges in Seed Biology - Basic and Translational Research Driving Seed Technology. Intech Open Limited, London, pp. 1-46.

41.Mahmoudi, H., Massoud, R.B., Baotour,O., Tarchone, I., Salah, I.B, Nasri, N., Adidi, W., Kaddour, R., Hannoufa, A., Lachaal, M., and Ouerghi, Z. (2012). Influence f different seed priming methods for improving salt stress tolerance in lettuce plants. J. Plant. Nutr. 35 (12): 1910-1922.

42.Mazed, H. E. M. K., Haque, N. M., Irin, I. J., Ashraful, M., Pulok, I., and Abdullah, A. A. M. (2015). Effect of seed priming on growth, yield and seed quality of chickpea BARI Chhola-6. 2015. Int. J. Multidiscip. 
Res. Dev. 2(7): 142-147.

43.Meena, R.P., Sendhil, R., Tripathi, S.C., Chander, S., Chhokar, R.S. and Sharma, R.K. 2013. Hydropriming of seed improves the water use efficiency of grain yield and economic return of wheat under different moisture regime. SAARC J. Agric. 11(2):149159

44.Mondal, S. and Bose, B. (2014). An impact of seed priming on disease resistance: A review. In: Kharwar, R. N., Upadhyay, R. S., Dubey, N. K., and Raghuwanshi, R. (eds), Microbial Diversity and Biotechnology in Food Security (1stEd.). Springer, New Delhi, pp.193-203.

45.Muhammad, I., Kolla, M., Volker, R., and Gunter, N. (2015). Impact of nutrient seed priming on germination, seedling development, nutritional status and grain yield of maize. J. Plant Nutr. 38: 1803-1821.

46.Nakamura, S., Teranishi, T., and Aoki, M. (1982). Promoting effect of polyethylene glycol on the germinaiton of celery and Spinach seeds. J. Japan. Soc. Hort. Sci. 50: 461-467.

47.Pame, A. R., Kreye, C., Johnson, D., Heuer, S., and Becker, M. (2015). Effects of genotype, seed $P$ concentration and seed priming on seedling vigor of rice. Exp. Agric. 51: 370- 381.

48.Paparella, S., Araujo, S. S., Rossi, G., Wijayasinghe, M., Carbonera, D., and Balestrazzi, A. (2015). Seed priming: State of the art and new prospectives. Plant Cell Rep. 34: 1281- 1293.

49.Raj, S. N., Shetty, N. P., and Shetty, H. S. (2004). Seed bio-priming with Pseudomonas fluorescens isolates enhances growth of pearl millet plants and induces resistance against downy mildew. Int. J. Pest Manag. 50(1): 41-48.

50.Sachs, J. (1859). About treatments modifying germination strength in seeds. Bot. Zeitung. 17: 177-188.

51.Sedghi, M., Nemat, A, and Esmielpour, B. 2012. Effect of seed priming on germination and seedling growth of two medicinal plants under salinity. Emir. J. Food Agric. 22 (2): 130-139.

52.Singh, A., Gupta, R., and Pandey, R. (2016). Rice seed priming with picomolar rutin enhances rhizosphericBacillus subtilis CIM colonization and plant growth. PLOS ONE. [e- journal] 11(1): e0146013. Available: journal.pone.0146013 [27 Nov. 2018].

53.Singh, D. K. and Pandey, U. B. (2003). Effect of hydration-dehydration and priming on seed germination and vigour of onion (Allium cepaL. var. Agrifound Dark Red) in field conditions. NHRDF Newsletter. 23 (4): $13-15$

54.Singh, H., Morss, S., and Orton, T. J. (1985). Effects of osmotic pretreatment and storage on germination of celery seed. Seed Sci. Technol. 13: 551-558.

55.Singh, H. B. (2016). Seed biopriming: A comprehensive approach towards agricultural sustainability. Indian Phytopathol. 69(3): 203-209.

56.Singh, C.V., Maiti, D., and Variar, M. (2012). Effect of seed treatment and weed management practices on the growth of crop and weeds and productivity of upland rice. In: Agriculture Diversification, Climate Change Management and Livelihoods.Proceedings of $3^{\text {rd }}$ International Agronomy Congress,26-30 November 2012, New Delhi, India

57.Singh, P. K., Pandita, V. K., Tomar, B. S., and Seth, R. (2015). Standardisation of priming treatments for enhancement of seed germination and field emergence in carrot. Indian J. Hortic. 72: 306-309.

58.Sivakalai, R. and Krishnaveni, K.2017. Effect of biopriming on seed yield and quality in pumpkincv $\mathrm{CO}$ 2. Int. Curr. Microbiol. App. Sci. 6 (12): 85-90.

59.Sivasubramaniam, K., Geetha, R., Sujatha, K., Raja, K., Sripunitha, A., and Selvarani, R. (2011). Seed priming: Triumphs and tribulations. Madras Agric. J. 98(7-9): 197-209.

60.Sun, H., Lin, L., Wang, X., Wu, S., and Wang, X. (2011). Ascorbate-glutathione cycle of mitochondria in osmoprimed soybean cotyledons in response to imbibitional chilling injury. J. Plant Physiol. 168:226232

61.Taylor, A. G., Allen, P. S., Bennett, M. A., Bradford, K. J., Burris, J. S., and Misra, M. K. (1998). Seed enhancements. Seed Sci. Res. 8(2): 245-256.

62.Varma, S. K., Jhorar, B.S., and Aggrwal, R.P. (1984). Effect of pre-sowing seed soaking in gibberellic acid ongermination and early seedling growth of cotton (Gossypium hirsutum L.). Cotton Dev. 14:23-28.

63. Venkatasubramanian, A. and Umarani, R. (2007). Evaluation of seed priming methods to improve seed performance of tomato (Lycoperisonesculentum), eggplant (Solanum elongena) and chilli (Capsicum annum). Seed Sci. Technol. 35(2): 487-490.

64.Yousof, F.I. (2013). Effect of rice seed priming with calcium chloride $\left(\mathrm{CaCl}_{2}\right)$ on germination and seedling vigor under salinity stress. Mansoura J. Plant Prodn. 4 (4):523-535. 